\title{
Students Need of Interactive Multimedia to Learn Language Skill
}

\author{
Biya Ebi Praheto ${ }^{1}$, Andayani ${ }^{2}$, Muhammad Rohmadi ${ }^{3}$, and Nugraheni Eko Wardani ${ }^{4}$ \\ \{biya.ebi@ustjogja.ac.id ${ }^{1}$, bu_anda09@yahoo.co.id ${ }^{2}$,rohmadi_dbe@yahoo.com ${ }^{3}$, \\ nugraheniekowardani_99@yahoo.co.id $\left.{ }^{4}\right\}$ \\ 1,2,3,4 Sebelas Maret University, Surakarta, Indonesia \\ ${ }^{1}$ Universitas Sarjanawiyata Tamansiswa, Yogyakarta, Indonesia
}

\begin{abstract}
This research aims to know students need of interactive multimedia to learn Indonesian language skill. It was conducted in the Department of Primary School Teacher Education during the even semester of 2016/2017 academic year. Data collection techniques were observation, interview and literature study. The data were then analyzed qualitatively descriptive by the stages of data reduction, data presentation, and conclusion. The result of this research shows that lecturers still implement conventional teaching by using power point and modules as well as dominating the speech method. In other hand, both students and lecturers state there needs to be interactive multimedia to help students during the learning process. Students need attractive multimedia to avoid boredom. Based on the result of observation, $98.62 \%$ of students state interactive multimedia should be given learning objective, $71.72 \%$ of them desire short and brief lesson, $27.59 \%$ desire detail explanation of material, $99.31 \%$ desire inclusion of language implementation example, $97.24 \%$ desire learning evaluation, $82.07 \%$ desire bright colors appearance, $12.41 \%$ desire dark colors appearance, $90.34 \%$ desire the inclusion of back sound and sound effect, $96.55 \%$ desire the inclusion of animation and picture, and 100\% students desire for menu button on interactive media for Indonesian language skill.
\end{abstract}

Keywords: students need, interactive multimedia, Indonesian language skill, primary school teacher education

\section{INTRODUCTION}

The learning of language has an important role in education since language is the communication tool required in all majors. Therefore, the teaching of language exists from the lowest education degree up to its highest. It is no exception in the Department of Primary School Teacher Education or Program Studi Pendidikan Guru Sekolah Dasar (PGSD). In this department (PGSD), Indonesian language becomes one of the mandatory courses in several courses, one of which is in the course of Indonesian Language Skill (Keterampilan Berbahasa Indonesia). This course covers four language skill aspects such as listening, speaking, reading, and writing. Indonesian language skill teaching in the Department of Primary School Teacher 
Education does not go apart from problems. Those problems are caused by factors from lecturers, students, or the learning materials. As educators, most lecturers do monotonous learning by using text-based power point. The un-innovative teaching impacts on less motivated students in the learning process. Besides, language skill learning materials do not only cover one aspect but four language aspects that the students consider as difficult. Such problems also happen in the Department of Primary School Teacher Education. Based on the result of observation, $63.45 \%$ of PGSD students taking skill course stated the course material is difficult. In other hand, $84.14 \%$ of students stated that their lecturers had used media for the learning; yet, $69.66 \%$ of students stated the media that the lecturers used were not interactive, and $74.48 \%$ of students stated that lecturers only used text-based power point media. Based on the result of interview with lecturers teaching Indonesian language skill, they mentioned using text-based power point even though at times they also use other teaching methods such as discussion, demonstration, and direct practice. The lack of teaching media causes the objective of the study has not maximally achieved. Expectation of Indonesian language skill learning in the Department of Primary School Teacher is the achieved learning objectives. The objective covers students' skill of Indonesian language on listening, speaking, reading, and writing. The linkage of objective and teaching material with primary school education is due to students are prospective teachers for primary school. Taking a look at the lack of teaching media in the learning of Indonesian language skill causes the teaching materials difficult to master by students and the objective of the learning does not maximally achieved.

Based on the problems mentioned above, there needs to be solution in order to make the learning of Indonesian language skill become effective. One of the solutions is by using innovative and interactive media to ease students to learn. One of the factors influencing the succeed of learning process is the use of teaching media [1]. Therefore, interactive media needs to be developed as a media that would help students learning process in the Department of Primary School Teacher. Ilhan and Oruc revealed that in a study on the use of multimedia in education improved students success, influenced their attitude in positive ways also made the learning interesting and easily understood [2]. Interactive multimedia is not a new media in education. It is often developed and created to help learning process. However, there has been no one developing interactive multimedia for the teaching of Indonesian language skill in the Department of Primary School Teacher Education. Some of the previous researches related to media and multimedia in the learning process are as follow. A research by Omar and Bidin discussing the impact of text and graphic multimedia in the learning of reading for children with autism [3]. Next, the research by Garcia, et al studied how multimedia help students to answer questions in the learning process [4]. Another research related to multimedia learning also conducted by Mukhopadhyay on a research implementing digital diversions in education as an interactive multimedia to motivate adult students in a unilateral scenario class [5]. The implementation of interactive media does not go apart from the implementation of technology in the learning. It was proven by the research of Alias, et al on the potency of video game in the learning of Malay language. The result of that research showed that video game was effectively potential in the learning of Malay language for foreign students [6]. The other research was conducted by Kassim where the result indicated that active, reflective, intuitive, and high visual of media made students creative after using the multimedia device [7].

The development of multimedia technology has changed the way people learn, obtain information as well as in interpreting information [8]. Multimedia is a combination of various media (format file) in the forms of text, picture, graphic, sound, animation, video, interaction and others packaged into digital file (computerized), used to deliver or convey message to public [9]. Next, Mayer defined multimedia as material presentation by using words and pictures [10]. Then, interactive multimedia is a multimedia equipped with controller tools that can be operated by users, so the users can choose what are desired for further process [11]. The teaching by using multimedia will enrich teaching content and time can be maintained as good as possible in the class, also it makes the learning not only centered on teachers and it fundamentally improves class efficiency [12]. Besides, Ruomei \& Feng in their research stated 
that multimedia could improve learning motivation and teaching efficiency [13]. Language skill covers four aspects namely listening, speaking, reading, and writing. All these four aspects are related to each other [14]. Nurjamal also mentioned that in fact those four aspects of language are skill related to each other. It means, one aspect of it strongly related and needs other aspects involvement [15]. Hermawan stated that listening skill is ones skill to understand words or sentences taught by interlocutors or certain media [16]. Speaking is one of the ways to communicate ideas through spoken message [17]. Besides, speaking can be interpreted as the ability to say language sounds to express or convey thoughts, ideas or feelings in written way [18]. Reading ability is an integral part of daily activities that is important for academic, personal and social [19]. Crawley and Mountain revealed that reading covers the activities of words introduction, literal understanding, interpretation, critical reading and creative understanding [20]. Next, writing can be interpreted as the activity of saying ideas in written way [21].

Taking a look from prior researches related to multimedia in the learning, there has been no research showing a research related to the development of interactive multimedia in the learning of Indonesian language skill learning in the Department of Primary School Teacher Education. Hence, the development of interactive multimedia in the learning of Indonesian language skill is a novelty development. To support the development of interactive multimedia in the learning of Indonesian language skill, there needs to be a study or initial research related to the need of the Department of Primary School Teacher Education students of interactive multimedia. Therefore, this research aims to analyze students' need of interactive multimedia on Indonesian language skill. The result of the analysis becomes one of the considerations to make and develop interactive multimedia in the learning of Indonesian language skill learning. It is expected that after knowing students' need of interactive multimedia, innovative and efficient interactive multimedia can be developed in accordance to the need of students so the objective of the learning can maximally be achieved.

\section{METHOD}

This is a qualitative case study research. Case study is an inquiry study where the researcher do in-depth exploration on certain event, activity, process, or one or some individuals [22]. Data are obtained from observation, interview, and document analysis. Case study allows investigation to maintain holistic and meaningful characteristic from the teaching and learning of real life [23]. This method is used to know the learning media used by lecturers in the learning of Indonesian language skill in the Department of Primary Teacher Education, also to analyze students' need of interactive multimedia to learn Indonesian language skill. This research involves lecturers, teaching and learning in the class. Cases in this qualitative case study research were limited by time and activity, and the researcher collected information completely by using various procedures of data collection based on the set time [24].

Subjects of this research were lecturers who taught Indonesian language skill and students studying it. This research was conducted in the Department of Primary School Teacher Education from universities in the Special Region of Yogyakarta and Central Java. This research focused on students' need of interactive multimedia to learn skills for students. Therefore, before analyzing students' need of interactive multimedia, it was required to know which media that were used by lecturers in the language skill learning. Data were taken from observation, interview, and documentation.

Then, data were obtained from interview. In a qualitative interview, the researcher could do face to face interview with participants or getting involved in focus group interview which consisted of six up to eight participants [25]. In association to this research, the interview was conducted for lecturers (DS) and students (MHS). Besides, document analysis was conducted for data triangulation. The documents collected by the researcher were power point that was used by lecturers, learning modules, course syllabus, also daily journals of the course. Data 
were analyzed qualitatively descriptive. It consisted of three activity flows occurring simultaneously namely data reduction, data presentation, and conclusion or verification [26]. Data reduction is a process of selection, centralization on simplification, abstraction, and rough data transformation that occur from written note in the field. After data selection in the field, the data were then presented narratively. Finally, the last step was making conclusion or verification. Conclusion was done simultaneously with reduction and data presentation. The result of conclusion was then examined for its validity by using data source triangulation.

\section{RESULT AND DISCUSSION}

The results of this research were obtained from observation and interview. The following are the results of interview and observation related to students' need of interactive multimedia to learn language skill.

\subsection{Observation Result}

Observation was conducted in class during the learning of Indonesian language learning. Among the observed things were learning materials, the media used in the learning, learning process and learning evaluation. Based on the result of observation, it was known that learning materials consisted of theory and practice. Theoretical materials related to four concepts of language such as listening, speaking, reading, and writing. Then, practice materials were also related to four language skills such as listening to news, listening to folklore, reading intensive discourse, telling interesting experience, speech, writing announcement, writing article, and many others. Those materials were directed to skill learning that would be taught to primary schools as examples of listening for children stories, listening for children songs, and telling interesting stories.

Next, it is related to the media used by lecturers in the learning, they are power point, learning modules, and recording for listening learning. Based on the observation of power point, it was more text-based containing theory materials. Further, speech by lecturers was dominating the learning process and students recorded the lesson. Besides, lecturers also implemented discussion model learning, question and answer, and also direct practice of language skill. Another thing observed by the researcher was learning evaluation. There was no special evaluation on theoretical materials. The lecturers evaluated students' understanding based on question and answer session and also discussion to know how far the students had understood the lesson. In association to practice, evaluation was conducted when students practicing language skill. For instance, in listening practice students should be able to retell what they had listened.

In addition to learning materials, the media used in the learning, learning process and evaluation, the desire or need of multimedia for the learning process is also presented in the table below.

Table 1. Need percentage of learning mulimedia

\begin{tabular}{llc}
\hline No. & Aspects in Multimedia & Student Percentage \\
\hline 1 & Learning objectives & $98.62 \%$ \\
2 & Short and brief material presentation & $71.72 \%$ \\
3 & Detail material presentation & $27.59 \%$ \\
4 & Example of language implementation & $99.31 \%$ \\
5 & Learning evaluation & $97.24 \%$ \\
6 & Bright colors appearance & $82.07 \%$ \\
7 & Dark colors appearance & $12.41 \%$ \\
8 & Back sound or sound effect & $90.34 \%$ \\
9 & Picture or animation & $96.55 \%$ \\
10 & Menu button & $100 \%$
\end{tabular}


Based on Table 1 above, it is known that most students desire multimedia with bright appearance accompanied with short and brief material presentation. Besides, students desire for learning objectives, learning evaluation, examples of language implementation, back sound, picture or animation, also menu button on the interactive mulimedia of Indonesian language skill learning that would be created.

\subsection{Interview Result}

Interview was conducted to know how the media is used in the learning, knowledge on interactive multimedia also students the need of interactive multimedia. The interview was conducted for lecturers who taught Indonesian language course as well as the students. The following are the results of interview of lecturers and students. In the media used during learning process. The media used were less innovative and were not attractive for students. Among those learning media were video, recording, power point, and learning modules. Most of the media were monotone and text-based such as power point that only consisted of written materials. On the basis of some problems one of which is the lack of interactive media, so the development of interactive media is required to help the learning process as well as to achieve the goal or objective of the planned learning. It is as what lecturers and students. The importance of multimedia is also stated by Wulan who was a lecturer teaching Indonesian language skill. Finally, it is related with interactive multimedia that would be developed. It does not go far from the result of observation that students desire multimedia which is as attractive as possible with the inclusion of example, animation, picture, and also sound in the interactive multimedia. It is in line with the following statement from lecturers and lecturers.

\subsection{Disscussion}

Based on the result of the research, it can be known that the learning of Indonesian language skill is still conducted conventionally. The media used were only text-based power point, learning modules also recording for listening learning. Besides, lecturers still do speech during the learning to convey the lesson and students make notes of the lesson. However, there were still other methods of teaching such as discussion, assignment, also language skill practice. In other hand, the learning of Indonesian language skill is a difficult thing especially on speaking and writing. It was due that both skills are productive skills. In fact, those skills have important roles in education. Ganapaty and Kaur stated that writing plays a very important role in the global classroom this day [27]. Students need to improve writing skill in order to be able effectively express ideas in academic field. It is in line with speaking skill which has important role in communication. Speaking is not only about "just speaking", but it also has to deliver information and convince the hearers as well. Kahlon also stated that effective communication related to the art of speaking in persuasive way in order to convince the hearers to know what is being spoken [28]. The art of speaking is the ability to speak well, to deliver message into its point, revealing the point of the present problems, only say what is needed, convincing and interesting, also about the ability to influence others. However, the two other skills namely listening and reading cannot be separated from those two other language aspects, also language skill has important role to create active learning. Chan, et al also mentioned similar thing, that active learning refers to the process that involves students in the activities of reading, writing, problem solving and reflecting [29]. By seeing from those occurrences, new innovation in the learning which is the implementation of interactive multimedia is needed. Either from the interview result or observation, it is shown that students need interactive multimedia in the learning of language skill to help the learning process. Interactive multimedia in the learning can be used as lecturers' communication aids with their students in delivering the teaching materials. Communication is a process of conveying or transferring information, ideas, feelings and thoughts of a party to the other parties [30]. In relation, lecturers can convey or communicate materials well to their students in the teaching and learning process and it can be helped by the use of interactive multimedia as the teaching media. Interactive multimedia is important for the process of learning is still conducted in 
conventional and monotonous way. Conventional teaching can decrease students' learning motivation as stated by Eaton in Ganapathy, et al. that teaching language using traditional method will only disappoint the learners who need constant motivation, inspiration, and guidance to express their creativity and innovation by using technology [31]. By interactive multimedia that acts as technological implementation in the learning, it will make the lesson interesting and fun. The use of technology in multimedia can create interactive system for students and give new knowledge as well as to develop creativity. Zin, et al revealed that similar thing of wide use of technology will create interactive system for students that shows the importance of multimedia in education [32]. In addition of giving knowledge, it can also inspire creativity that leads to creation of new experience. Based on the interview with students, similar result is also shown on the understanding of multimedia. Students desire attractive multimedia that is attached animation and music, yet proper appearance of the multimedia should be considered in order not to disturb students' focus on learning materials. Besides, lecturers also revealed that multimedia is attractive with nice colors, pictures, animation, sound, video, and other multimedia stuffs. The multimedia integrating various elements as mentioned has not been utilized by lecturers because they still do conventional teaching. The elements of multimedia such as video, sound, picture, animation, and text are strongly important in designing teaching media as stated by Nawi and Zakaria in creating the portal design of IPBL (Islamic Problem Based-Learning) [33]. Nawi and Zakaria said that the selection of media elements such as video, text, picture and supporting materials based on teaching strategy are given emphasis in the creation phases of this form. Multimedia elements meant here are video, picture, audio and text. From the description above, it is known that students need interactive multimedia in learning Indonesian language skill. Students do not only need multimedia in the class, but also for outside class use that can be operated independently by them, so the developing interactive multimedia as technology in the teaching will ease students to learn the lesson any time. Shea, Pickett, \& Li mentioned that technology in the present day has been broadly used to make higher degree of education can be accessed by students [34].

Besides, students desire multimedia that is made as attractive as possible to avoid boredom and also added with the inclusion of animation picture or back sound . Lesson presentation should be made short and brief along with suitable bright colors, also including menu icon so students can easily select the learning materials. Thus, in addition to utilize computer device, multimedia can make the learning goes interactively. Shao stated that the power of lesson delivered through computer is the ability to create a situation where the learners learn independently or in group and also to interact with the learning material and reference sources [35]. This interactivity makes learning elements under the control of learners that allow them as individuals to approach the lesson with their own actions. In relation to the development of interactive multimedia, it will be created according to the need of students that have been explained above. Multimedia can be created interactively by combining various elements such as text, pictures, animation, sound, video, and proper colors. Those elements will make multimedia attractive for students as learners. Ahmad, et. al stated that application in video is more attractive and draw more attention of the users, while narrative musical background is added to make it more effective to influence the users [36].

Besides, evaluation will be put in interactive multimedia both in material and practice ways as well as including the example of Indonesian language skill implementation. In other hand, the multimedia will be given menu icon that will ease students to choose what lesson they want to learn. Hence, multimedia is not only one way used by the educators but also for students. Multimedia does not only deliver teaching materials cognitively but students can also get involved in the utilization of interactive multimedia in the learning of Indonesia language skills. It helps students to easily understand the lesson. Akin stated that every individual can remember $10 \%$ of what they read, $20 \%$ of what they hear, $30 \%$ of what they see, $50 \%$ of what they see and hear, $70 \%$ of what they say, and $90 \%$ of what they do and say [37]. Therefore, multimedia should be created as interactive as possible not only presenting lessons but also 
turning students to do direct practice [38]. Thus, it is expected that the objective of the learning will be achieved maximally through interactive multimedia that will be implemented in the learning.

\section{Conclusion}

Interactive multimedia has important roles in the learning process. It can help students to learn the teaching materials to maximally achieve the objective of the learning. The result of this research shows that lecturers still implement conventional teaching by using power point and modules as well as dominating the speech method. Besides, both students and lecturers state that there needs to be interactive multimedia to help students during the learning. It can be concluded that students give positive response on interactive multimedia that would be developed in the learning of Indonesian language skill. Then, the multimedia will be created according to the needs of students which is creating interactive multimedia by combining various elements such as text, picture, animation, sound, and proper colors. Not only that, evaluation in material or practice manners will be put and the example of Indonesian language skill implementation will be. . In other hand, menu icon will also be put on the multimedia so it will ease the students to choose the teaching materials or lessons they want to learn. By seeing that, multimedia is not only used as one way by the lecturers, but it can also be used by students too. Next, multimedia does not only deliver teaching materials cognitively, but students can also get involved in the utilization of interactive multimedia in the learning of Indonesian language skill.

\section{ACKNOWLEDgment}

Our gratitude goes to the Ministry of Technology Research and Higher Education of the Republic of Indonesia for the full support through the grant program of Doctoral Dissertation Research (Penelitian Disertasi Doktor) with contract number of: PDD.DIKTI.01/UST/LP3M/K/III/2018.

\section{REFERENCES}

[1] A. T. Ampa, "The Implementation of Interactive Multimedia Learning Materials in Teaching Listening Skills,” English Lang. Teach., vol. 8, no. 12, p. 56, 2015.

[2] G. O. Ilhan and Ş. Oruç, "Effect of The Use of Multimedia on Students' Performance : A Case Study of Social Studies Class," Acad. Educ. Res. Rev., vol. 11, no. 8, pp. 877-882, 2016.

[3] S. Omar and A. Bidin, "The Impact of Multimedia Graphic and Text with Autistic Learners in Reading,” vol. 3, no. 12, pp. 989-996, 2015.

[4] J. D. García, E. Rigo, and R. Jiménez, "Multimedia and Textual Reading Comprehension : Multimedia as Personal Learning Environment's Enriching Format," vol. 6 , no. 1, 2017.

[5] T. P. Mukhopadhyay, U. De Guanajuato, and S. Diego, "Digital Diversions in Education: Interactive Multimedia for Adolescent Motivation in Unilateral Classroom Scenarios," vol. 3, no. 2, pp. 60-74, 2017.

[6] N. Alias, F. Rosman, M. Nazri, A. Rahman, and D. Dewitt, "The potential of video game in Malay language learning for foreign students in a public higher education institution," Procedia - Soc. Behav. Sci., vol. 176, pp. 1020-1027, 2015.

[7] H. Kassim, "The relationship between learning styles , creative thinking performance and multimedia learning materials," Procedia - Soc. Behav. Sci., vol. 97, pp. 229-237, 2013.

[8] A. A. Ziden and Muhammad Faizal Abdul Rahman, "The Effectiveness of Web-Based Multimedia Applications Simulation in Teaching and Learning," Int. J. Instr., vol. 6, no. 2, pp. 211-222, 2013. 
[9] Munir, Multimedia: Konsep \& Aplikasi dalam Pendidikan. Bandung: Alfabeta, 2012.

[10] Ricard E. Mayer, Multimedia Learning. Yogyakarta: Pustaka Pelajar, 2009.

[11] Daryanto, Inovasi Pembelajaran Efektif. Bandung: Yrma Widya, 2013.

[12] C. Patel, "Use of Multimedia Technology in Teaching and Learning communication skill \&quot; : An Analysis,” Int. J. Adv. Res. Technol., vol. 2, no. 7, pp. 116-123, 2013.

[13] F. Ruomei and M. Feng, "THE USE OF MULTIMEDIA IN CHINESE LANGUAGE TEACHING 印尼建国大学多媒体中文教学 Binusmaya 网络教学系统, ” vol. 3, no. 2, pp. 392-399, 2012.

[14] K. Saddhono and YT. Slamet, Pembelajaran Keterampilan Berbahasa Indonesia: Teori dan Aplikasi Edisi 2. Yogyakarta: Graha Ilmu, 2014.

[15] Nurjamal, Terampil Berbahasa: Penuntun Perkuliahan Bahasa Indonesia di Perguruan Tinggi. Bandung: Alfabeta, 2014.

[16] Asep Hermawan, Metodologi Pembelajaran Bahasa Arab. Bandung: PT Remaja Rosdakarya, 2011.

[17] Dedi Efrizal, “Improving Students' Speaking through Communicative Language Teaching Method at Mts Ja-alhaq, Sentot Ali Basa Islamic Boarding School of Bengkulu, Indonesia,” Int. J. Humanit. Soc. Sci., vol. 2, no. 20, pp. 127-134, 2012.

[18] G. Brown and Yule, Discourse Analysis. Cambridge: Cambridge University Press, 1996.

[19] Haryono, "THE EFFECTS OF MULTIMEDIA LEARNING AND VOCABULARY MASTERY ON STUDENTS ' JAPANESE READING SKILLS,” Ling. Cult., vol. 10, no. 1, pp. 43-47, 2016.

[20] S. J. Crawley and L. Mountain, Strategies for Guiding Content Reading. Boston: Allyn and Bacon, 1995.

[21] Djago Tarigan, Teknik Pengajaran Keterampilan Berbahasa. Bandung: Penerbit Angkasa, 1986.

[22] John W. Creswell, Research Design: Qualitative, Quantitative, and Mixed Methods Approaches - Thrid Edition. California: Sage Publications, 2009.

[23] S. Mohamed, K. A. Jasmi, and M. A. Zailaini, "SOCIAL SCIENCES \& HUMANITIES Elements of Delivering Islamic Education through Islamic Morality in Several Malaysian Schools," vol. 24, no. 4, pp. 1267-1277, 2016.

[24] John W. Creswell, Research Design: Pendekatan Kualitatif, Kuantitatif dan Mixed. Yogyakarta: Pustaka Pelajar, 2014.

[25] John W. Creswell, Educational Research: Planning, Conducting, and Evaluating Quantitative and Qualitative Research - 4th Ed. Boston: Pearson Education, 2012.

[26] M. B. Miles and A. M. Huberman, Analisis Data Kualitatif. Jakarta: UI Press, 2014.

[27] M. Ganapathy and S. Kaur, "SOCIAL SCIENCES \& HUMANITIES Engaging ESL Students in the Writing Classroom Through the Multiliteracy Approach," vol. 21, no. 2, pp. 547-568, 2013.

[28] M. Kahlon, "SOCIAL SCIENCES \& HUMANITIES Art of Speaking - An Impression of Man: Analysing the Need for Communication and Soft Skills," vol. 21, no. 2, pp. 657-666, 2013.

[29] Y. F. Chan, G. K. Sidhu, N. Suthagar, L. F. Lee, and B. W. Yap, "Relationship of Inquiry-based Instruction on Active Learning in Higher Education," Pertanika J. Soc. Sci. Humanit., vol. 24, no. S, pp. 55-72, 2016.

[30] K. A. Wahab and Z. Hamid, "HAMBATAN MEMAHAMI BAHASA: SATU PENELITIAN KE ATAS TEKS BERITA DALAM TALIAN BERBAHASA INDONESIA , TEMPO . CO BARRIERS IN UNDERSTANDING LANGUAGE : A STUDY ON INDONESIAN LANGUAGE," vol. 31, no. 2, pp. 493-514, 2015.

[31] M. Ganapathy, M. Shuib, T. Gunasegaran, and S.N. Azizan, "ESL Lecturers' Perceptions on using i-MoL as a Mobile-Based Tool for Teaching Grammar," Pertanika J. Soc. Sci. Humanit., vol. 23, no. 3, pp. 1069-1085, 2016.

[32] M. Zaid, M. Zin, A. Asmadi, and N. Azlina, "Relationship Between the Multimedia Technology and Education in Improving Learning Quality,” Procedia - Soc. Behav. Sci., 
vol. 90, no. InCULT 2012, pp. 351-355, 2013.

[33] A. Nawi, G. Abdul, N. Zakaria, E. Of, and I. Portal, "PEMBANGUNAN DAN PENILAIAN PORTAL IPBL DI," vol. 32, no. 1, pp. 415-444, 2016.

[34] N. Adams and A. Porter, "Video Enhanced Multiple Choice Questions - Personalising eLearning," Pertanika J. Soc. Sci. Humanit., vol. 24, no. S, pp. 41-54, 2016.

[35] J. Shao, "A Study of Multimedia Application-based Vocabulary Acquisition," vol. 5, no. 10, pp. 202-207, 2012.

[36] J. Ahmad, G. Sritharan, and N. N. A. M. Nasir, "The Effectiveness of Video and Pamphletes in Influencing Youth on Enviromental Education,” J. Komun. - Malaysian J. Commun., vol. 31, no. 1, pp. 281-293, 2015.

[37] E. Akin, "Observation of multimedia-assisted instruction in the listening skills of students with mild mental deficiency," vol. 11, no. 5, pp. 182-193, 2016.

[38] K. Saddhono, "Cultural and social change of foreign students in Indonesia: The influence of Javanese Culture in Teaching Indonesian to Speakers of Other Languages (TISOL)." IOP Conf. Ser.: Ear. and Envi. Sci.. vol. 126 no. 1 IOP Publishing, 2018. 